\title{
The Criminal Sanctions Implementation of Personnel Sexual Violence on Under Age's Children (Minors)
}

\author{
Afandi $^{*}$ and Umar Ma'ruf ${ }^{* *}$ ) \\ *) Student of Master of Law, Universitas Islam Sultan Agung Semarang and Head \\ District Police of Dukupuntang-Cirebon, E-mail: afandi mh35@std.unissula.ac.id \\ ${ }^{* *}$ Lecturer of Master of Law, Universitas Islam Sultan Agung Semarang
}

\begin{abstract}
The objectives of this research are: To analyze and explain implementation of criminal sanctions for perpetrators of sexual violence against minors. To analyze and explain constraints and solutions implementation of criminal sanctions for perpetrators of sexual violence against minors. The method used by researchers is a sociological juridical legal approach and the specifications in this study are descriptive. Based on the results of the research that the implementation of criminal sanctions for perpetrators of sexual violence against minors according to Act No. 23 of 2002 can be implemented and applies Article 82 of Act No. 23 of 2002 and Article 290 paragraph 2 of the Criminal Code that the defendant is proven to have fulfilled the objective elements and The subjective elements contained in both articles carry a maximum penalty of 15 years in prison and a minimum of 3 years in prison. The obstacles are: a) when the perpetrator of a criminal act of sexual violence against children knows that he has been reported by the victim to the police. b) The investigator has limited time in processing files of the crime. c) Lack of information about the perpetrator also makes it more difficult for investigators to find the perpetrator. d) It is difficult for the investigator to obtain information from the victim who has severe trauma. e) In investigating criminal acts of sexual violence against children, one of the steps the investigator takes to obtain evidence of a criminal act of sexual violence against children is to take a post mortem. The solution is: a) the investigator takes steps to collaborate with the police from various regions to find the whereabouts and secure the perpetrator.

Keywords: Children; Sexual Violence; Execution; Perpetrator; Criminal Sanctions.
\end{abstract}

\section{Introduction}

Children are the hope of the nation in the future, the rights that must be obtained by children against their parents since the child is born in this world based on the applicable laws and regulations. Legal protection of children can be interpreted as legal protection of various freedoms and children's freedoms of children) and various interests related to the welfare of children. ${ }^{1}$

A visionary view, children are a form of investment that is an indicator of the success of a nation in implementing development. The success of child development will determine the quality of human resources in the future. ${ }^{2}$ Article $28 \mathrm{~B}$ paragraph (2) of the 1945 Constitution of the Republic of Indonesia (hereinafter abbreviated to UUDNRI 1945) states that:

\footnotetext{
${ }^{1}$ Waluyadi. (2009). Hukum Perlindungan Anak. Bandung: Mandar Maju. p. 1

2 Suyanto, Bagong. (2003). Pekerja Anak dan Kelangsungan pendidikannya. Surabaya: Airlangga University Press. p. 21
} 
Children have a strategic role and the state guarantees the rights of every child to live, grow and develop as well as protection from violence and discrimination. Therefore, the best interests of children should be lived out as the best interests for the survival of humanity. ${ }^{3}$

Actions of violence that occur in the community are increasingly unsettling. In resolving a conflict or problem accompanied by acts of violence. In general, acts of violence can be defined as the deliberate use of physical force or force, actual threats or violence against oneself, other people, or against a group or community, which results in injury or is likely to injure, kill, harm psychologically, or develop abnormalities or loss. There are many forms of violence, including physical violence, verbal violence, psychological violence, economic violence, symbolic violence and neglect. ${ }^{4}$

Violence against children is a fairly complex problem, because it has serious negative impacts, both on the victim and on the social environment. In general, violence is defined as an act committed by one individual against another individual that results in physical and/or mental disorders. Act No. 23 of 2003 concerning Child Protection. Article 4 states that: Every child has the right to be able to live, grow, develop and participate fairly in accordance with human dignity and dignity, and receive protection from violence and discrimination. ${ }^{5}$

The term sexual harassment is defined as a criminal act in which an adult touches a minor for sexual gratification, for example rape (including sodomy).

Child sexual abuse can result in both short and long term harm, including psychopathology at a later date. Its psychological, emotional, physical and social impacts include depression, post-traumatic stress disorder, anxiety, eating disorders, low self-esteem, personal identity disorder and anxiety; common psychological disorders such as somatization, neurological pain, chronic pain, changes in sexual behavior, school/study problems; and behavioral problems including drug abuse, selfharm, animal cruelty, adult crime and suicide. The specific character pattern of the symptoms has not been identified and there are several hypotheses on this causality association.

The objectives of this study are as follows: To analyze and explain the implementation of criminal sanctions for perpetrators of sexual violence against minors. To analyze and explain the obstacles and solutions to the implementation of criminal sanctions for perpetrators of sexual violence against minors.

\section{Research methods}

This research uses a juridical sociological/socio-legal research approach, where in this research the technical steps taken follow the social science assessment patterns,

\footnotetext{
${ }^{3}$ Elucidation of the Law of the Republic of Indonesia Number 11 of 2012 concerning the Juvenile Criminal Justice System

${ }^{4}$ Aan Hardiansyah, Akhmad Khisni, Jawade Hafidz, Violence in the Teaching and Learning Process Viewed from the Perspective of Criminal Law and Law No. 14 of 2005 on Teachers and Lecturers, Jurnal Daulat Hukum Vol. 1. No. March 1, 2018 ISSN: 2614-560X, Unissula

${ }^{5}$ Act No. 23 of 2003 concerning Child Protection
} 
especially sociology and law. ${ }^{6}$. The specification in this research is descriptive analytical, that is, research that describes in detail the social phenomena that are the subject of the problem. Descriptive research is intended to provide data as accurate as possible about humans, conditions or other symptoms.

\section{Results and Discussion}

\subsection{Implementation of Criminal Sanctions for Perpetrators of Sexual Violence Against Minors}

In the context of social life, everyone cannot escape from various reciprocal relationships and interrelated interests which can be viewed from various aspects, for example from a religious, ethical, socio-cultural, political, and legal perspective. Judging from the diversity of interests, it often creates conflicts of interest, which in turn give birth to what is called a crime. In order to protect these existing interests, rules and legal norms are made that must be obeyed. Against a person who violates the rule of law and causes harm to other people, action will be taken in the form of compensation or a fine, while a person who has committed a criminal act will be sentenced to a criminal sanction in the form of a body sentence both imprisonment, A law enforcer in carrying out legal procedures to sanction children in conflict with the law or in these special situations, must use a special paradigm. This is very necessary because the sanctions given must be able to provide educational value, and the nature of the sanctions must be in accordance with the philosophical meaning. ${ }^{7}$

To protect children from the influence of the formal process of the criminal justice system, human or legal and humanitarian experts think to make formal rules for removing a child who has violated the law or committed a criminal act from the criminal justice process by providing other alternatives which is considered better for the child. ${ }^{8}$

The main problem related to law enforcement lies in the factors that influence it. These factors are as follows: ${ }^{9}$

- The legal factor itself

- Law enforcement factors, namely the parties who form or implement the law

- Factor of means or facilities that support law enforcement.

- Community factors, namely the environment in which the law applies or is applied.

- Cultural factors, namely as a result of work, creativity and taste based on initiative in social life.

\footnotetext{
${ }^{6}$ Soekanto, Soerjono. (1983). Faktor-Faktor Yang Mempengaruhi Penegakan Hukum. Jakarta: Rajawali, p.60

${ }^{7}$ Rendy Surya Aditama, Umar Ma'ruf, Munsharif Abdul Chalim, Criminal Law Policy Against Children as Perpetrators of Psychotropic Crimes at the Magelang Police, Journal of Daulat Hukum Vol. 1. No. March 1, 2018 ISSN: 2614-560X, Unissula

${ }^{8}$ Fiska Ananda, Application of Diversion as Efforts to Protect the Law Against Children of Criminal Offenders, Journal of Daulat Hukum Vol. 1. No. March 1, 2018 ISSN: 2614-560X, Unissula

${ }^{9}$ Op.Cit. Soekanto, Sarjono. p. 5
} 
Basically, a person who has committed a criminal act can be subject to a criminal witness if the act fulfills the elements of a criminal act. The elements of a criminal act that must be fulfilled include, among others, an act that fulfills the formulation of a law and is against the law committed by a person or group of people deemed capable of being responsible. The criminal act of fornication with violence is threatened in articles $285 \& 289$ of the Criminal Code stipulates "Whoever is with violence or threats. Violence forces a woman to have sexual relations with him outside of marriage, is threatened with decency, with a maximum sentence of twelve years"

In the Criminal Code (KUHP), provisions regarding criminal sanctions against perpetrators of sexual violence are actually regulated, but in fact these crimes still occur in many places and are hidden in people's lives. It is not uncommon for these cases to escape the applicable law, some even stop at the level of examination by the police or the prosecutor's office so that they do not reach the court process. In order to achieve the success of law enforcement in eradicating the rampant cases of sexual violence, it is very necessary to strengthen the coordination of serious cooperation from the police, prosecutors and judges in court. The verdicts of judges examining sexual violence cases in various courts vary. There are even cases of sexual violence against minors who were only sentenced to play with the sentence of six months imprisonment. This can be justified because within the maximum and minimum limits (one day to twelve years) the judge is free to receive the correct sentence). ${ }^{10}$

Crime in general is an evil deed or act committed by a human being which is considered unkind, despicable and inappropriate. Crime is an anti-social act that is harmful, inappropriate, and cannot be tolerated which can cause shocks in society. ${ }^{11}$

Every year, cases of sexual violence in Indonesia have increased. The victims are not only adults, but now they also include teenagers, children and even toddlers. The phenomenon of sexual violence against children has become more frequent and has become global in almost all countries. Cases of sexual violence against children continue to increase from time to time. This increase was not only in terms of quantity or number of cases, but also in terms of quality. And what is even more tragic is that most of the perpetrators are from the family environment or the environment around the child, including in his own house, school, educational institution, and the child's social environment. ${ }^{12}$

In cases of molestation against minors, there are many problems regarding how the law enforces justice for perpetrators of sexual immorality who are punished with penalties which can be said that the punishment cannot make the behavior of the perpetrators change for the better, so this causes the victim to feel that he is not getting it efficient justice by what crimes the perpetrator has committed against the

\footnotetext{
${ }^{10}$ Kendal Regency, Khaira Ummah Legal Journal Vol. 12. No. March 1, 2017, Unissula M. Sholeh, Sri Endah Wahyuningsih, Analysis of the Application of Criminal Sanctions to Perpetrators of Criminal Offenses of Child Sexual Violence at the Demak District Court, Khaira Ummah Journal of Law Vol. 12. No. June 2, 2017, Unissula

${ }^{11}$ B. Simandjuntak. (1981). Pengantar Kriminologi dan Patologi Sosial. Bandung: Tarsito. p. 71.

${ }^{12}$ Ivo Noviana. 2015. Sexual Violence Against Children: Impact and Management. Socio Informa Vol. 01, No. January 1 - April 2015. Center for Social Welfare Research and Development: Ministry of Social Affairs of the Republic of Indonesia
} 
victims, especially minors. Law is a rule for humans, so law enforcement or law enforcement must provide benefits or benefits to society. ${ }^{13}$

The implementation of criminal sanctions for perpetrators of sexual violence against minors according to Act No. 23 of 2002 can be implemented and applies Article 82 of Act No. 23 of 2002 and Article 290 paragraph 2 of the Criminal Code that the defendant is proven to have fulfilled the objective and subjective elements contained in Both articles carry a maximum penalty of 15 years in prison and a minimum of 3 years in prison.

\subsection{Constraints and Solutions for the Implementation of Criminal Sanctions for Perpetrators of Sexual Violence Against Minors}

Early childhood has the right to get a decent living and protection, and can grow and develop optimally. In Act No. 23 Year 2002 Article 4 concerning Child Protection, that is, every child has the right to be able to live, grow, develop and participate fairly in accordance with human dignity and protection from violence and discrimination. Failure to protect children threatens national development and has a negative and costly impact, which will carry over until the children become adults. ${ }^{14}$

In Indonesian positive law, protection of children's rights can be found in various laws and regulations, as stated in Presidential Decree No. 36 of 1990 which is a ratification of the United Nations convention on children's rights (Convention on the rights of the child), Act No. 39 of 1999 concerning Human Rights, Act No. 35 of 2014 concerning Amendments to Act No. 23 of 2002 concerning Child Protection, Act No. 17 of 2016 concerning the establishment of government regulations in lieu of Act No. 1 of 2016 concerning the second amendment to Act No. 23 of 2002 concerning Child Protection into law and Act No. 112012 concerning the Child Criminal Justice System. ${ }^{15}$ This is a gateway to be able to protect the rights of children in conflict with the law and can guarantee protection for children in criminal justice with the best consideration for the child. So that for the effectiveness of law work, all stakeholders must have a progressive character, not conventional anymore. ${ }^{16}$

The theory of legal culture explains that law is basically not just a black and white formula as outlined in various forms of legislation, but law should be seen as a symptom that can be observed in people's lives through the behavior patterns of its citizens. ${ }^{17}$ In general, it can be said that legal protection includes activities that are direct and indirect from actions that endanger children physically and/or psychologically. As for the process of legal protection for child victims of sexual abuse, the principle of justice for children is emphasized. That is justice in every child's case must reflect a sense of justice for the child. In addition, it is also necessary to consider

\footnotetext{
${ }^{13}$ Teguh Prasetyo, Judge's Decision on Child Abuse at the Pekalongan City District Court (Case Study at the Pekalongan City State Court), Khaira Ummah Legal Journal Vol. 13. No. March 1, 2018, Unissula

${ }^{14}$ Dan O'Donnell. (2006). Perlindungan Anak: Buku Panduan bagi Anggota Dewan Perwakilan Rakyat. Unicef in collaboration with the Inter Parliamentary Union. p. 4

${ }^{15}$ Setiawan, Doni. (2012). Urgensi Peradilan Restoratif Dalam Hukum Pidana Anak Indonesia. Semarang:

Unissula Press. p. 10.

${ }^{16}$ Suteki. (2015). Masa Depan Hukum Progresif. Yogyakarta: Thafa Media. p. 80.

${ }^{17}$ Ishaq. (2008). Dasar-dasar Ilmu Hukum. Jakarta: Sinar Grafika. p. 10
} 
the best interests of the child, namely that all decision making must always consider the child's survival and development. ${ }^{18}$

Legal protection for children who are victims of decency crimes can include forms of protection that are abstract (indirect) or concrete (direct). Abstract protection is basically a form of protection that can only be enjoyed or felt emotionally (psychologically), such as satisfaction. Meanwhile, concrete protection is basically a form of protection that can be enjoyed in real terms, such as gifts that are either material or non-material. Giving that is material in nature can be in the form of compensation or restitution, free living expenses or education. The provision of nonmaterial protection can be in the form of freedom from threats, from news that is degrading to humanity. ${ }^{19}$

There are several obstacles to implementing criminal sanctions for perpetrators of sexual violence against minors, namely:

- When the perpetrator of the crime of sexual violence against children knows that he has been reported by the victim to the police.

- The investigator has limited time in processing files of the crime.

- Lack of information about the perpetrator also makes it more difficult for investigators to find the perpetrator.

- The investigators had difficulty getting information from the victim who had severe trauma.

- In investigating criminal acts of sexual violence against children, one of the steps the investigator takes to obtain evidence of a criminal act of sexual violence against children is to take a post mortem.

Efforts to overcome obstacles to the implementation of criminal sanctions for perpetrators of sexual violence against minors include:

- The investigators took steps in collaboration with police officers from various regions to find the whereabouts and secure the perpetrator.

- In the implementation of disclosing criminal acts of sexual violence against children that are still not maximal,

- For children who are victims of criminal acts of sexual violence against children, especially in cases of sodomy and children who have suffered severe physical and psychological trauma, the investigator provides assistance from a psychologist.

- Investigators for parents of children who are perpetrators or victims of criminal acts of sexual violence against children are to provide motivation and provide the best solutions for the lives of these children in the future.

- Investigators establish communication and provide supervision of perpetrators or victims of criminal acts of sexual violence against children who have served their sentence.

\footnotetext{
${ }^{18}$ Kismanto, Anis Mashdurohatun, Legal Justice for Child Victims of Sexual Violence in Kendal Regency, Khaira Ummah Legal Journal Vol. 12. No. March 1, 2017, Unissula

${ }^{19}$ Sri Endah Wahyuningsih, Legal Protection of Children as Victims of Crime of Decency in Current Positive Criminal Law, Jurnal Pembaharuan Hukum Volume III No. May 2 - August 2016, Unissula
} 


\section{Closing}

The implementation of criminal sanctions for perpetrators of sexual violence against minors according to Act No. 23 of 2002 can be implemented and applies Article 82 of Act No. 23 of 2002 and Article 290 paragraph 2 of the Criminal Code that the defendant It is proven that it fulfills the objective elements and subjective elements contained in both articles with a maximum penalty of 15 years in prison and a minimum of 3 years in prison. For children who are victims of criminal acts of sexual violence against children, especially in cases of sodomy and children who have suffered severe physical and psychological trauma, the investigator provides assistance from a psychologist. $d$. The investigators provide motivation and provide the best solutions for the lives of these children in the future. e. Investigators establish communication and provide supervision of perpetrators or victims of criminal acts of sexual violence against children who have served their sentence.

The government should be able to financially help victims and their families from criminal acts of sexual violence against children who are less fortunate or be able to provide subsidies for financing from the post mortem process so that it does not burden the victim and his family Investigators can collaborate in the mechanism for handling children who are victims of criminal acts of sexual violence against children by opening special services. Improve the quality of legal protection for children who are victims and witnesses of criminal acts of sexual violence against children so that children can be guaranteed their survival and livelihood as part of human rights.

\section{References}

\section{Journals}

[1] Aan Hardiansyah, Akhmad Khisni, Jawade Hafidz, Violence in the Teaching and Learning Process Viewed from the Perspective of Criminal Law and Law No. 14 of 2005 on Teachers and Lecturers, Jurnal Daulat Hukum Vol. 1. No. March 1, 2018 ISSN: 2614-560X, Unissula

[2] Ivo Noviana. 2015. Sexual Violence Against Children: Impact and Management. Socio Informa Vol. 01, No. January 1 - April 2015. Center for Social Welfare Research and Development: Ministry of Social Affairs of the Republic of Indonesia

[3] Fiska Ananda, Application of Diversion as Efforts to Protect the Law Against Children of Criminal Offenders, Jurnal Daulat Hukum Vol. 1. No. March 1, 2018 ISSN: 2614-560X, Unissula

[4] Kismanto, Anis Mashdurohatun, Legal Justice for Child Victims of Sexual Violence in Kendal Regency, Khaira Ummah Legal Journal Vol. 12. No. March 1, 2017, Unissula

[5] M. Sholeh, Sri Endah Wahyuningsih, Analysis of the Application of Criminal Sanctions to Perpetrators of Criminal Offenses of Child Sexual Violence at the Demak District Court, Khaira Ummah Journal of Law Vol. 12. No. June 2, 2017, Unissula 
[6] Rendy Surya Aditama, Umar Ma'ruf, Munsharif Abdul Chalim, Criminal Law Policy Against Children as Perpetrators of Psychotropic Crimes at the Magelang Police, Jurnal Daulat Hukum Vol. 1. No. March 1, 2018 ISSN: 2614-560X, Unissula

[7] Sri Endah Wahyuningsih, Legal Protection of Children as Victims of Crime of Decency in Current Positive Criminal Law, Jurnal Pembaharuan Hukum, Volume III No. May 2 - August 2016, Unissula

[8] Teguh Prasetyo, Judge's Decision on Child Abuse at the Pekalongan City District Court (Case Study at the Pekalongan City State Court), Khaira Ummah Legal Journal Vol. 13. No. March 1, 2018, Unissula

\section{Books}

[1] B. Simandjuntak. (1981). Pengantar Kriminologi dan Patologi Sosial. Bandung: Tarsito

[2] Suyanto, Bagong. (2003). Pekerja Anak dan Kelangsungan pendidikannya. Surabaya: Airlangga University Press

[3] Dan O'Donnell. (2006). Perlindungan Anak: Buku Panduan bagi Anggota Dewan Perwakilan Rakyat. Unicef in collaboration with the Inter Parliamentary Union

[4] Setiawan, Doni. (2012). Urgensi Peradilan Restoratif Dalam Hukum Pidana Anak Indonesia. Semarang: Unissula Press

[5] Ishaq. (2008). Dasar-dasar Ilmu Hukum. Jakarta: Sinar Grafika

[6] Soekanto, Soerjono. (1983). Faktor-Faktor Yang Mempengaruhi Penegakan Hukum. Jakarta: Rajawali

[7] Suteki. (2015). Masa Depan Hukum Progresif. Yogyakarta: Thafa Media

[8] Waluyadi. (2009). Hukum Perlindungan Anak. Bandung: Mandar Maju

\section{Regulation}

[1] Act No. 23 of 2003 concerning Child Protection 